\title{
Karstifikasi dan Pola Struktur Kuarter Berdasarkan Pemetaan Lapangan dan Citra SRTM Pada Formasi Wapulaka, Pasar Wajo, Buton, Sulawesi Tenggara
}

\author{
Yuniarti Yuskar $^{1}$, Harisma ${ }^{2}$, Tiggi Choanji ${ }^{1}$ \\ ${ }^{1}$ Program Studi Teknik Geologi Universitas Islam Riau \\ ${ }^{2}$ Fakultas Ilmu dan Teknologi Kebumian Universitas Halu Oleo
}

\begin{abstract}
Karstification process occurs as a result of dissolution on limestone lithology formed in typical morphology of caves, rounded or elongated pits and conical hills. This also related with structural pattern that also intesively occurs at western part of Buton Island. Research area located at lattitude $5^{0} 27^{\prime} 0^{\prime \prime} \mathrm{S}-5^{0} 32^{\prime} 0^{\prime \prime} \mathrm{S}$ and longitude $122^{\circ} 49^{\prime} 30^{\prime \prime} \mathrm{E}-122^{\circ} 52^{\prime} 30^{\prime \prime}$ E. Purpose of this research was to identified karst landscape and karstificatiom process on Wapulaka Formation and recognize the structural pattern on this formation. By using field observation and SRTM data interpretation we considered that karst formations formed on Wapulaka Formation was Quarter limestone which diagenesis process of dissolution forming karst landform also related with uplifted event at pliocene - pleistocene. This formed related with complex interaction between the geology, climate, hydrology and biological factors that created various landscape morphology such as caves, underground river, stalagtite, stalagmite and others cave ornament.
\end{abstract}

Keywords: Karst, Limestone, Structural pattern, Wapulaka formation, Buton

Corresponding Author e-mail address: yuniarti_yuskar@eng.uir.ac.id

\section{PENDAHULUAN}

Daerah penelitian terletak di Daerah Pasar Wajo, Pulau Buton Sulawesi Tenggara. Secara geografis berada pada koordinat Latitude $5^{0} 27^{\prime} 0^{\prime \prime}$ LS - 5 $32^{\prime} 0^{\prime \prime}$ LS dan longitude $122^{\circ} 49^{\prime} 30^{\prime \prime}$ BT - 122 $52^{\prime} 30^{\prime \prime}$ BT (Gambar 1). Daerah ini merupakan Ibu kota Kabupaten Buton yang terletak di pesisir bagian timur Pulau Buton.

Formasi Wapulaka yang terdapat di Pulau Buton terbentuk oleh proses struktur geologi yang kompleks, terdiri dari Batugamping berumur Kuarter berbentuk platform dan dikontrol oleh tipe pelarutan pada proses diagenesis yang membentuk morfologi karst, morfologi ini merupakan bentangalam yang khas yang terbentuk dari pelarutan batuan seperti batugamping, marble, dan gypsum (Ford and Williams, 2007). Daerah ini memiliki struktur yang cukup kompleks akibat tumbukan antara mikro lempeng buton - muna - dan tukang besi (Satyana, 2011). Maka penelitian ini bertujuan mengidentifikasi proses kartifikasi dan pola struktur pada Formasi Wapulaka di Pulau Buton. Penelitian ini melingkupi analisis geomorfologi, struktur dan diagenesis yang terbentuk pada Formasi ini.

\section{Geologi Regional}

Wilayah Buton merupakan bagian dari fragmen mikrokontinen yang diantaranya terdiri dari Pulau Buton, Pulau Muna dan Pulau Tukang Besi yang saling berhubungan dan mempengaruhi ketika terjadi kolisi diantaranya. Terjadinya tumbukan awal antara Pulau Muna dan Pulau Buton menyebabkan obduksi kerak samudra Muna dan Buton membentuk rangkaian pegunungan ofiolit disebut sebagai Kapantoreh dengan litologi batuan ultrabasa peridotit yang berumur Eosen - Oligosen. Tumbukan awal 
ini juga menyebabkan terjadinya sesar-sesar naik lokal dan lipatan thin skinned (Yuskar, Y. 2014). Selanjutnya terjadi kolisi kedua antara Pulau Buton dan Tukang Besi, Efek awal dari kolisi mikrokontinen tersebut terekam pada kala Pliosen Akhir, ditandai dengan terbentuknya batugamping terumbu pada blok-blok naik serta batugamping foraminiferal packestone dan napal terendapkan pada blok turunan. Kolisi yang kedua ini menyebabkan bagian Selatan Buton lebih terangkat dibandingkan bagian utara, dibuktikan dengan distribusi batugamping terumbu Pleistosen dibagian selatan dan lingkungan estuarin dibagian utara (Smith, 1982).

Fokus penelitian merupakan Formasi Wapulaka yang terdiri dari batugamping Grainstone yang masif, kristalisasi walaupun masih dapat terlihat fragmen-fragmen organik berupa skeletal maupun pecahan cangkang. Kehadiran batugamping chalky juga masih terlihat dengan jelas disertai adanya fragmen koral, molluska, alga dan cangkang pelecypoda, selain itu terdapat batugamping grainstone yang juga telah banyak mengalami kristalisasi. Kontak satuan diendapkan selaras diatas satuan batulempung karbonatan.Satuan ini berumur Pleistosen dengan lingkungan pengendapan yaitu Litoral - Neritik Dalam (Yuskar, Y. 2014).

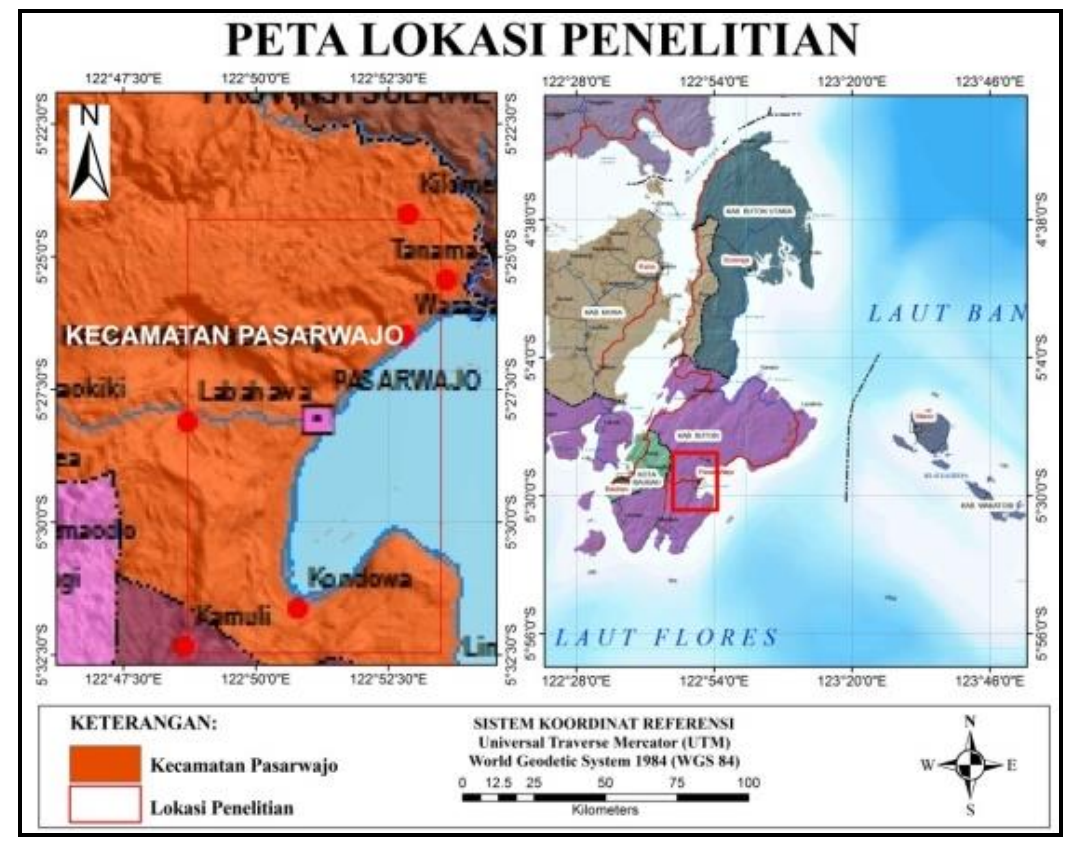

Gambar 1 Lokasi Penelitian

Struktur yang berkembang pada pulau buton memang masih menjadi misteri, dikarenakan masih terdapat perbedaan dalam pembentukan pulau tersebut. Hamilton 1979 menyatakan bahwa buton dan tukang besi adalah satu fragmen mikro kontinen dari bagian barat Muna dan dan barat pulau Buton. Namun Fortuin et al 1990, Davidson 1991, dan Tanjung et al 2007 menyatakan bahwa platform Buton dan Tukan Besi adalah dua mikro kontinen yang saling terpisah. Buton mengkolisi Muna pada awal miosen, tukang besi selanjutnya pada akhir pliosen. Efek awal dari tabrakan mikro-benua ButonTukang Besi dicatat pada akhir strata Pliosen terumbu berkembang pada blok yang terangkat sementara packstones foraminifera laut dalam dan napal yang diendapkan pada blok dibawahnya. Tabrakan kedua menghasilkan efek pengangkatan intensif di Buton selatan dibandingkan dengan utara, sebagaimana 
dibuktikan oleh distribusi terumbu berumur plistosen dan perkembangan estuari dan penurunan atol di utara.

Morfologi dari Formasi ini memperlihatkan undak-undak pantai purba dan topografi karst, endapan hancuran terumbu, batukapur (chalk), batugamping pasiran, batupasir gampingan, batulempung dan napal yang kaya foraminifera planktonik, diendapkan pada lingkungan lagun-litoral, tebal satuan diperkirakan $700 \mathrm{~m}$.

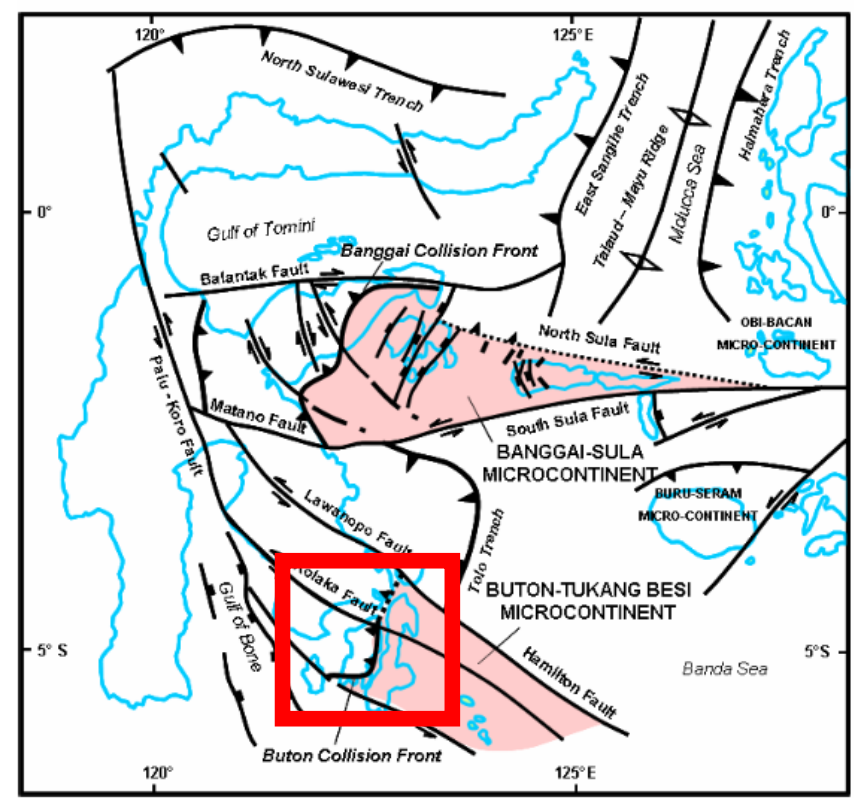

Gambar 2 Kolisi Lengan bangian tenggaran antara mikrokontinen Buton - Tukang Besi (Satyana, 2011).

\section{Bentangalam Karst}

Karst adalah suatu bentang alam yang khas dari muka bumi maupun bawah permukaan, yang terutama dibentuk oleh pelarutan pengendapan batuan karbonat oleh aliran air tanah. Proses pelarutan tersebut umumnya dibarengi dengan oleh proses proses lainnya seperti runtuhan, transport dalam bentuk larutan melalui saluran bawah tanah, juga longsoran dan amblesan dipermukaan. Proses karastifikasi tersebut berlangsung selama jutaaan tahun dan akhirnya menghasilkan kondisi bentangalam seperti yang ada sekarang (Ibnu Maryanto, 2006).

Fenomena Karst terutama terjadi pada daerah yang terbentuk dan tersusun dari endapan batuan karbonat (linestone) dengan mineral utama kalsit (CaCO3), aragonit (CaCO3) dan dolomit $(\mathrm{CaMg}(\mathrm{CO} 3) 2$ tetapi dapat juga terjadi pada batuan lain yang terbentuk dari mineral-mineral mudah larut oleh air lainnya seperti gipsum (Ca2SO4. 2H2O), anhidrit ( $\mathrm{CaSO} 4)$, halit $(\mathrm{NaCl})$, batuan sedimen kalsit dengan semen yang mudah larut, maupun batuan lain dimana proses pelarutan mineral bisa dan mudah terjadi (Ibnu Maryanto, 2006).

Proses utama pembentukan bentangan alam Karst adalah pelarutan. Batugamping dan dolomit mudah terlarutkan oleh air. Pelarutan yang terjadi secara terus menerus, pada akhirnya menciptakan bentukan alam yang sangat beragam (Hanang Samodra, 1996). 
Tipe karst ditentukan menggunakan klasifikasi Balazs (1973; dalam Jennings, 1985). Klasifikasi bukit karst dibagi oleh Balazs berdasarkan kepada rasio antara diameter (d) dengan tinggi (a) bukit karst. Dari hasil pembagian itu, Balazs membagi atas empat tipe yaitu:

1. Tipe Yangzhou d/a $<1,5$ dikenal sebagai kars mogote atau kars menara. Di Indonesia contoh paling baik adalah pada kawasan kars Maros-Pangkep, Sulawesi Selatan dan sebagian di Lintau-Buo-Sawahlunto, Sumatera Barat.

2. Tipe Organos d/a 1,5 - 3 dikenal sebagai cockpit karst, bukit berbentuk kerucut dengan sinkhole membintang. Di Indonesia contoh paling baik adalah di Pegunungan Kars Karangbolong, Gombong Selatan, Jawa Tengah.

3. Tipe Gunungsewu d/a $3-8$ dikenal sebagai bukit pepino, umumnya berbentuk kubah yang membulat. Sesuai dengan penciri tipenya, contoh terbaik di Indonesia adalah di plateau kars Gunungsewu, Yogyajarta-Jawa Tengah, atau di Pangandaran, Jawa Barat.

4. Tipe Tual $\mathrm{d} / \mathrm{a}>8$ bukit kars umumnya sangat landai sehingga secara pengamatan sekilas tidak memperlihatkan sebagai bukit kars. Selain di Tual, Maluku, contoh lain dapat dikenali sebagian di Jampang Tengah, Jawa Barat. diperlihatkan dengan pembentukan menara-menara karst karena proses karstifikasi berjalan relatif cepat secara vertikal.

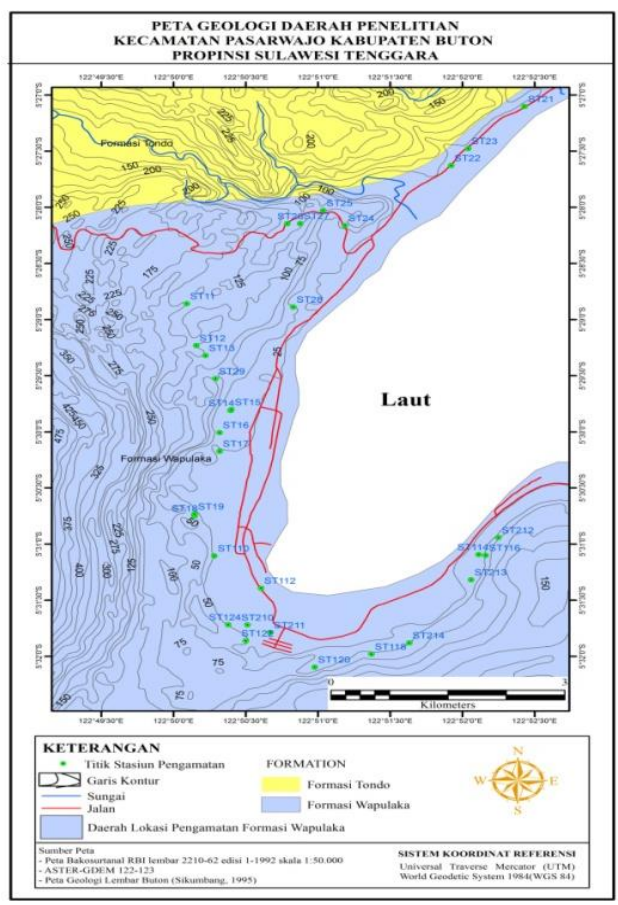

Gambar 3 Peta Geologi Daerah Pasarwajo

\section{METODE PENELITIAN}

Metode penelitian yang dilakukan dalam pengamatan ini yaitu menggunakan metode observasi lapangan, diaman dilakukan pengamatan secara langsung untuk memperoleh data yang akurat. Pengamatan yang dilakukan dilapangan yaitu dengan melihat objek geomorfologi atau bentang alam karst dan mengamati gejala-gejala proses karstifikasi yang terdapat dalam Goa - Goa yang berada di lokasi daerah penelitian. Disertai dengan pengolahan data struktur dan data SRTM untuk mengamati 
pola kelurusan - kelurusan yang menandakan adanya pengaruh struktur yang cukup kuat di daerah tersebut. Dan juga dilakukan pengambilan sampel yang berupa data-data dokumentasi untuk membuat pelaporan terhadap kondisi dari pengamatan lapangan.

Data-data pengambilan sampel yang dilakukan berupa proses atau fenomena-fenomena dari proses karstifikasi atau proses pelarutan yang terdapat dalam bentuk lahan karst daerah penelitian, seperti ornamen-ornamen dalam gua yang berupa stalaktit dan stalagmit. Fenomena-fenomena tersebut hampir keseluruhan terdapat disetiap pembentukan goa-goa yang dipengaruhi oleh tingkat curah hujan dan ketebalan dari jenis litologi penyusun batuan.

\section{HASIL DAN PEMBAHASAN Pola Struktur}

Pola umum struktur pada Pulau Buton yaitu timurlaut - baratdaya yang menunjukkan sesar-sesar naik yang terbentuk akibat kolisi antara Pulau Muna - Buton - Tukang Besi (Gambar 4a). Berdasarkan pola - pola kelurusan yang terbentuk pada data SRTM, pola struktur daerah penelitian memiliki arah yang relatif sama yaitu berarah timurlaut - baratdaya (Gambar 5). Pola tersebut menunjukkan pola punggungan yang memanjang yang diindikasikan sebagai akibat zona sesar naik yang tidak lepas dari adanya pengaruh tumbukan Muna-Buton-Tukang besi. Berdasarkan kondisi kenampakan olahan data kemiringan lereng, pola kelurusan struktur sangat tampak dengan trend yang berarah timurlaut baratdaya, hal ini diinterpretasikan bahwa kondisi platform pada saat mikro kontinen saling bertumbukan juga memiliki trend yang sama yaitu berarah relatif timurlaut - baratdaya membentuk batugamping yang tumbuh aktif.

Pada bagian barat daerah penelitian Formasi Wapulaka memiliki kontak selaras dengan Formasi Sampolakosa dan dibatasi oleh adanya sesar naik. Sesar naik ini teridentifikasi dengan adanya indikasi struktur geologi berupa cermin sesar yang ditemukan pada stasiun Y-94. Bidang cermin sesar pada stasiun Y-94 (Gambar 5) yang diukur pada foot wall menunjukka strike / dip bidang sesar N $30^{\circ} \mathrm{E} /$ $50^{\circ}$, pitch $25^{\circ}$ berarah timurlaut (Yuskar, Y. 2014). Formasi Wapulaka merupakan batuan karbonat terumbu berumur Pliosen Akhir yang terbentuk pada blok-blok naik akibat thrusting dan asosiasi batugamping lainnya seperti batugamping grainstone dan rudstone pada bagian depan maupun belakang tubuh terumbu tersebut dan berada pada lingkungan laut dangkal berkisar antara littoral-inner neritic. Hal ini menandakan relatif turunnya mukalaut sehingga dapat mendukung terbentuknya batuan karbonat terumbu yang terendapkan secara selaras diatas Formasi Sampolakosa yang merupakan batulempung karbonatan. 

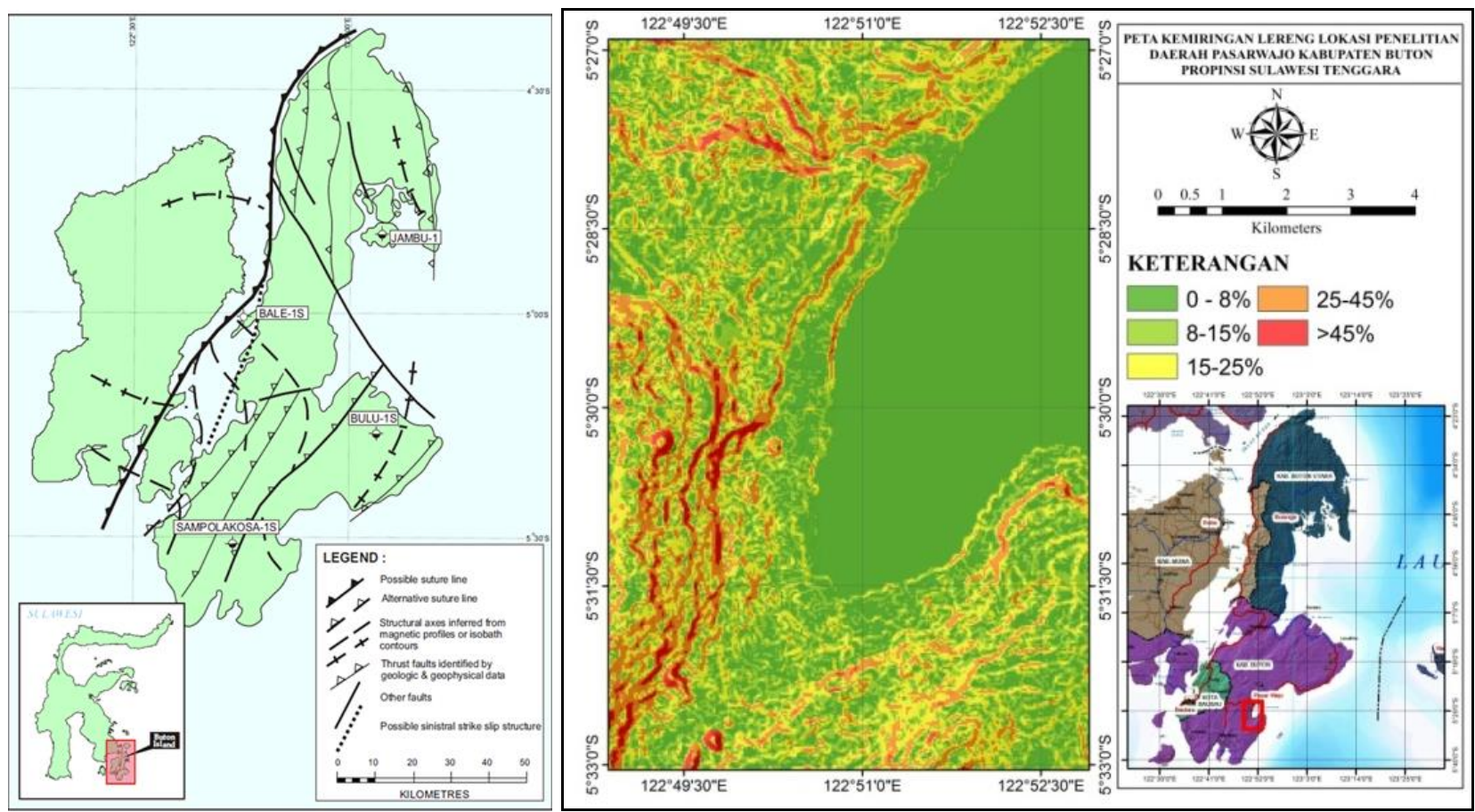

Gambar 4 a. Peta struktur pulau Muna dan Buton yang menunjukkan respon tektonik kolisi (Bon dan Livsey, 2004). (Kanan) dan b. Peta Kemiringan Lereng Daerah Pasar Wajo memperlihatkan arah orientasi bentangalam Karst. (kiri)

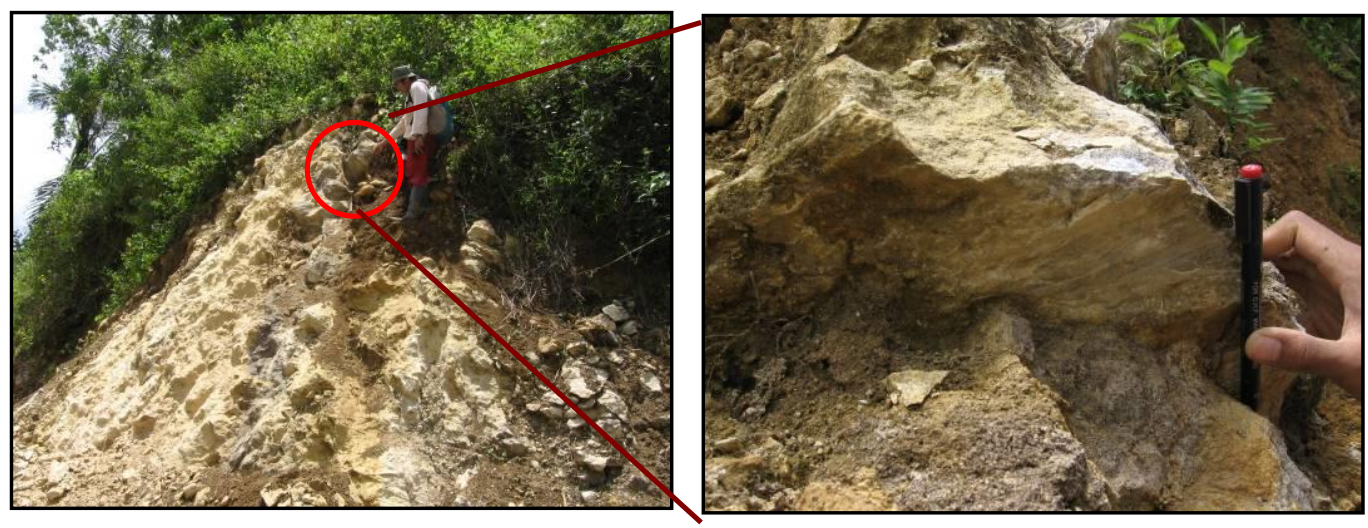

Gambar 5 Singkapan dan Cermin Sesar pada stasiun Y-94

\section{Karstifikasi}

Bentangalam Karst minor yang dijumpai pada daera penelitian berupa alur-alur dengan bentuk yang khas seperti solution pits, facers, flutes maupun runnel (Gambar 5). Bentangalam karst utama berupa perbukitan yang terjal yang merupakan eksokarst positif. Perbukitan Karst Daerah Pasar Wajo terlihat di sepanjang jalan utama dari Pasar Wajo hingga Kota Bau-Bau. Pola-pola bentang alam karst Daerah Pasar Wajo berdasarkan pengamatan lapangan menyerupai bukit pepino dan dinding-dinding karst yang diakibatkan proses pelarutan secara vertikal yang intensif (Gambar 6a). Bukit pepino memiliki elevasi 250 - $400 \mathrm{~m}$ dari permukaan laut (Gambar 6b) terbentuk dari batukapur yang didominasi oleh batugamping grainstone. 
Batugamping grainstone (Gambar 7a) memiliki deskripsi putih krem (segar), krem kehitaman (lapuk), berukuran butir pasir sedang - kasar, ditemukan struktur skeletal alga, pelecypoda, gastropoda, dibeberapa bagian terdapat mineral-mineral hasil dari rekristalisasi, porositas baik, permeabilitas baik, keras - sangat keras, dengan morfologi perbukitan yang landai.
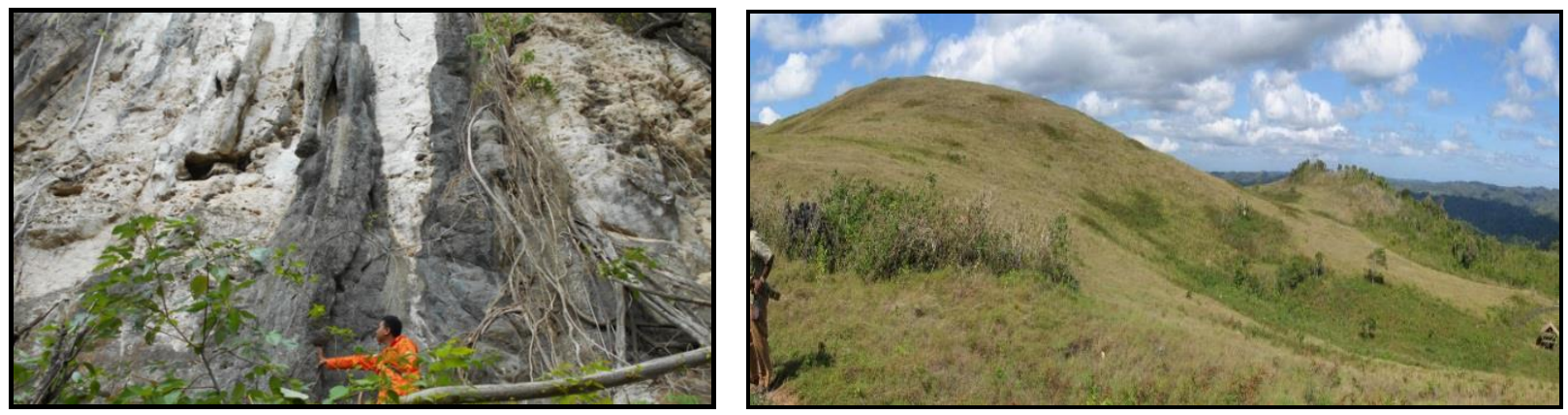

Gambar 6 a. Proses Pelarutan pada dinding tebing karst membentuk alur (kiri) dan b. Bentangalam Bukit Pepino (kanan)
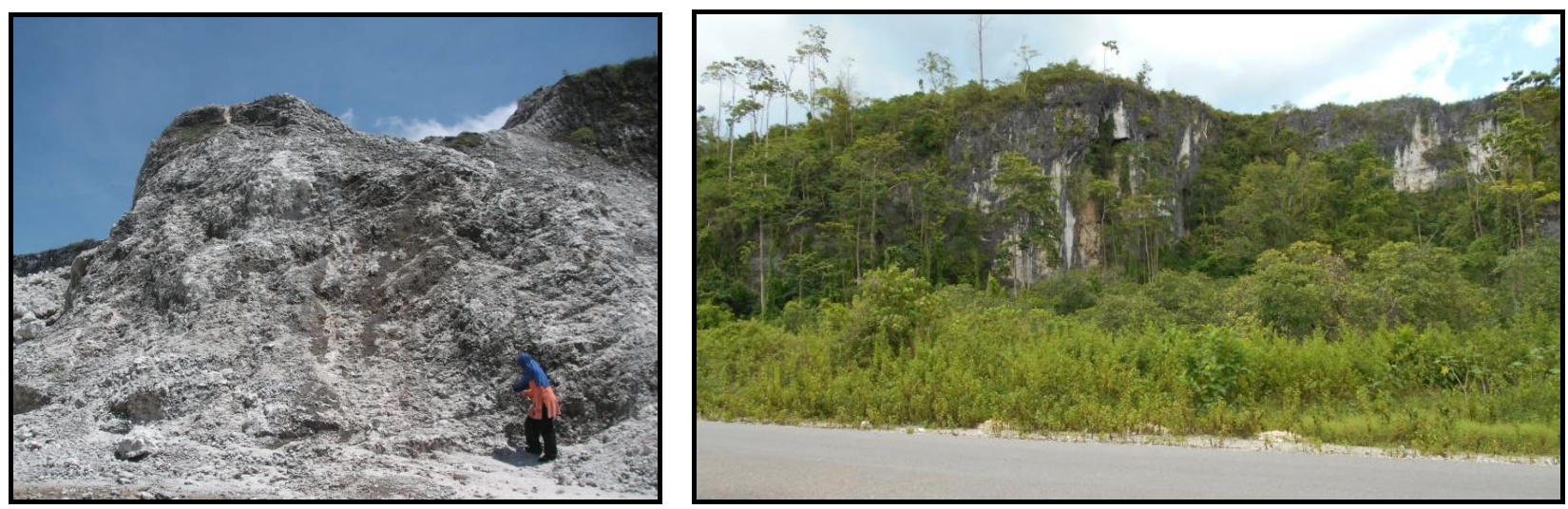

Gambar 7 a. Batugamping grainstone dan Morfologi perbukitan tebing yang curam (kiri) dan b. bagian atas merupakan plate (kanan)

Bentuk tebing karst sangat terlihat Di bagian selatan daerah penelitian. Pada bagian atas tebing karst menunjukkan suatu pedataran yang landai dan perbukitannya membentuk bukit-bukit yang tidak berbentuk kerucut akan tetapi lebih memperlihatkan bentuk yang datar yang disebut plateau (Gambar $7 b)$.

Perbukitan karst di Daerah Pasar Wajo ini sebagian sudah mengalami perubahan bentuk seperti menara dan lebih memperlihatkan dinding-dinding karst yang menyerupai seperti benteng yang memiliki ketinggian tebing-tebing karst kurang lebih 50-85 meter (Gambar 8). 


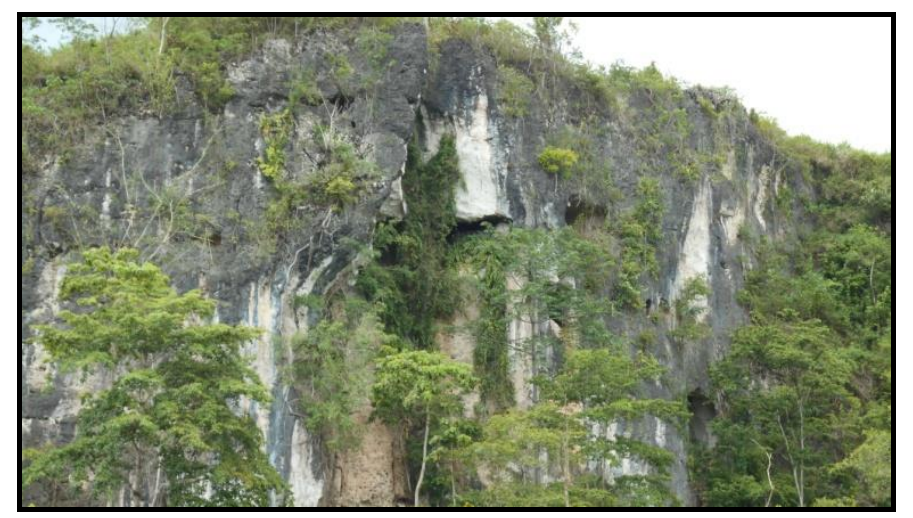

Gambar 8 Morfologi perbukitan karst bagian selatan Pasarwajo dengan tebing yang curam

Endokarst berupa gua-gua dan ornamen-ornamen gua juga terlihat selain dari bentangalam karst minor dan bentangalam Karst Mayor. Keberadaan goa-goa yang terdapat pada lokasi penelitian berada di kota Pasarwajo dengan akses lokasi yang sangat baik untuk dilalui karena merupakan jalur utama untuk aktivitas masyarakatnya. Keterdapatan goa-goa yang berada di daerah penelitian sebagian di manfaatkan sebagai sarana sumber air utama untuk kebutuhan sehari-hari. Keterdapatan goa-goa pada area penelitian hampir seluruhnya berada pada topografi pedataran sehingga keterdapatan sumber airnya sangat dipengaruhi oleh pasang surut air laut.

Beberapa kenampakan goa-goa yang terdapat pada daerah penelitian meliputi:

1. Gua Wandingi

Goa Wandini (Gambar 9a) berlokasi di Desa Wandingi, Kecamatan. Pasarwajo. Mulut gua berarah Utara - Selatan dengan lebar mulut gua $15 \mathrm{~m}$ dan tinggi mulut gua $25 \mathrm{~m}$, dari dasar mulut gua ke atas permukaan gua memiliki tinggi mencapai $40 \mathrm{~m}$. Gua ini memiliki sedikit ornament dan merupakan batugamping berlapis mendatar dan terdapat sumber mata air sekitar $25 \mathrm{~m}$ dari mulut gua.

\section{Gua Laka Sombu}

Gua Laka Sombu (Gambar 9b) berlokasi di Desa Banabungi, Kecamatan Pasarwajo. Arah mulut gua yaitu Timur-Barat. Gua ini terbentuk dari batugamping grainstone, bidang perlapisan mendatar, terdapat kekar, lebar mulut gua $3.5 \mathrm{~m}$, tinggi mulut gua $4 \mathrm{~m}$. tidak dijumpai ornament-ornamen gua, di jumpai bongkahan batugamping.
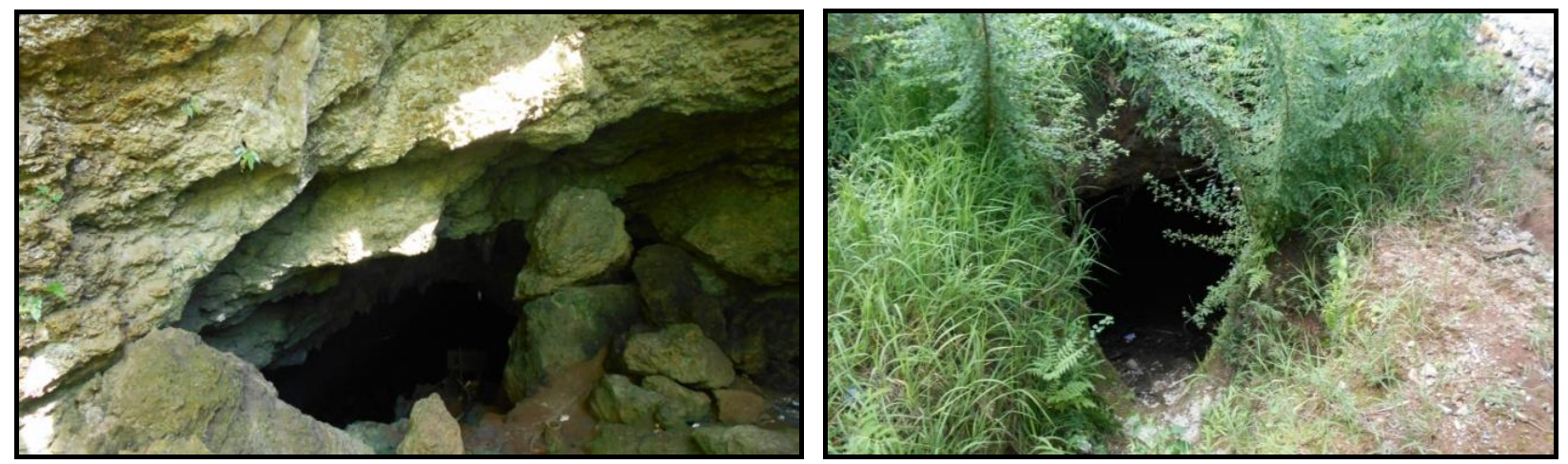

Gambar 9 a. Kenampakan Gua Wandini (kiri) dan b. Kenampakan Laka Sombu (kanan). 


\section{Gua Larumusu}

Gua Larumusu (Gambar 10a) berlokasi di Desa Banabungi, Kecamatan Pasarwajo. Arah mulut gua Timurlaut-Baratdaya, lebar mulut gua $10 \mathrm{~m}$ dan tinggi mulut gua $4 \mathrm{~m}$. terdapat mata air yang jaraknya $7 \mathrm{~m}$ dari mulut gua ke sumber mata air. Mata airnya di jadikan sebagai sarana sumber air bagi penduduk setempat. Pada gua ini tidak dijumpai ornamen gua dan tersusun dari batugamping grainstone.

\section{Gua Wakaitai}

Gua Wakatai berlokasi di Desa Takawa, Kecamatan Pasarwajo. Arah mulut gua berarah barat lauttimur laut, lebar mulut gua $10 \mathrm{~m}$ dan tinggi mulut gua $6 \mathrm{~m}$, tinggi keseluruhan $25 \mathrm{~m}$. Terdapat sumber air dengan jarak $15 \mathrm{~m}$ dan terdapat ornamen stalagtit dan terdiri dari batugamping grainstone yang bewarna putih (gambar 10b).
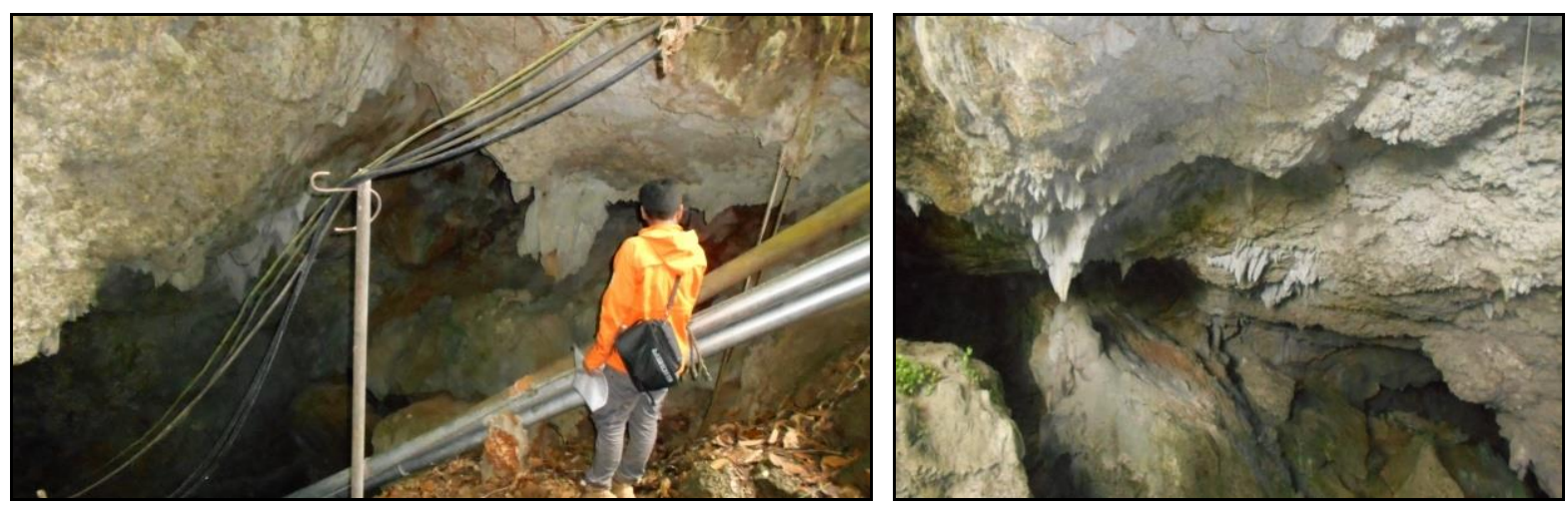

Gambar 10 a. Kenampakan Gua Larumusu (kiri) dan b. Gua Wakaitai (kanan)

\section{KESIMPULAN}

1. Daerah Pasar Wajo memiliki trend pola struktur yang relatif berarah timurlaut - barat daya dengan posisi platform yang sejajar dengan pola struktur membentuk daerah tinggian dibagaian barat dan rendahan di bagian timur.

2. Bentangalam Karst yang terdiri dari Perbukitan Karst dengan tipe Gunung Sewu dan endokarst berupa gua-gua. Tipe Gunung Sewu berupa Bukit Pepino dan plateu. Perbukitan Karst ini tersusun dar batukapur dan batugamping grainstone. Terdapat beberapa gua di Pasa Wajo yaitu Gua Wandingi, Laka Sombu, Laramusu, Wakatai. Dalam proses pembentukan karst sangat dipengaruhi oleh cuaca dan iklim. Dalam pemanfaatan wilayah karst haruslah memperhatikan aspek lingkungan sehingga kelestarian wilayah karst dapat terjaga dan dimanfaatkan secara optimal.

\section{DAFTAR PUSTAKA}

Bon, J. and Livsey, A. (2004). Buton Prospectivity Screening Study. Jakarta: PT Horizon (unpublished). 
Balazs, D. (1973). Relief Types Of Tropical Karst Areas. Proceedings of the symposium on karstmorphogenesis, International Geographical Union, European region conference (Hungary), 1632.

Davidson, J.W. (1991). The Geology and Prospectivity of Buton Island, S.E. Sulawesi Indonesia. Proceeding IPA 20th, Jakarta.

Ford, D.C., and Williams, P.W. 2007. Karst Geomorphology and Hydrology. Chichester: John Wiley and Sons

Samudra, Hanang. (2011). Nilai Strategis Kawasan Kars Di Indonesia. Bandung: Pusat Pengembangan Dan Pengembangan Geologi.

Maryanto, Ibnu, et al. (2006). Manajemen Bioregional: Kars, Masalah dan Pemecahannya, Dilengkapi Kasus Jabodetabek. Bogor: Puslit Biologi LIPI.

Satyana, A.H., Irawan, C., Kurniawan, W. (2013). Revisit Geology And Geochemistry Of Buton Asphalt Deposits, SE Sulawesi: Implications For Petroleum Exploration Of Buton Area. Proc. Indonesian Petroleum Association Thirty-Seventh Annual Convention \& Exhibition, IPA13-G170

Satyana, A.H., M.E.M. Purwaningsih. (2011). Collision of Microcontinents With Eastern Sulawesi: Records From Uplifted Reef Terraces and Proven-Potential Petroleum Plays. Proc. Indonesian Petroleum Association, IPA11-G-219

Sikumbang, N, dkk. (1995). Peta geologi Lembar Buton. Pusat Penelitian dan Pengembangan Geologi. Bandung.

Smith, R.B. (1982). Sedimentology and Tectonics of a Miocene Collision complex and Overlying Late Orogenic Clastic Strata, BUton Island, Eastern Indonesia. A Dissertation, University of California.

Smith, R.S.U. (1989). Remote Sensing Study of Late Neogene Structures, Buton Island, Sulawesi, Indonesia. Conoco Technical Service Report 8654-F20-002-1-89. 43p.

Tanjung, H, dkk. (2007). Trend of Petroleum Exploration in Buton: An Insight From Tectonic, Stratigraphic and Geochemical Aspect. Proceeding IPA 21th, Jakarta.

Yuskar, Y. (2014). Interpretasi Fasies Pengendapan Formasi Tondo, Pulau Buton, Sulawesi Tenggara Berdasarkan Data Pemetaan Geologi dan Potensinya Sebagai Batuan Reservoir Minyak bumi. Journal of Earth Energy Engineering, Vol 3 No. 1, Pekanbaru.

Yuskar, Y. (2014). Stuktur Geologi dan Model Tektonostratigrafi Daerah Gonda dan sekitarnya Kecamatan Sorawolio, Kabupaten Buton Sulawesi Tenggara. Jurnal RAT Vol. 3 No. 2, Pekanbaru. 